\title{
Impact of Total Quality Management and Service Quality in the Banking Sector
}

\section{Faisal Talib ${ }^{1 *}$, Zillur Rahman² and Qureshi MN ${ }^{3}$}

${ }^{1}$ Mechanical Engineering Section, University Polytechnic, Aligarh Muslim University, Aligarh, India ${ }^{2}$ Department of Management Studies, Indian Institute of Technology, Roorkee, India

${ }^{3}$ Department of Mechanical Engineering, Faculty of Engineering and Technology, M.S. University of Baroda, Vadodara, India

\begin{abstract}
After the successful implementation of TQM in manufacturing it is now being extensively applied in service sectors including banks, to improve business performance. Keeping this in view, the purpose of this paper is to present a detailed overview of the role of service quality and Total Quality Management (TQM), and its critical dimensions in the banking sector. A detailed review of the literature on TQM and service quality concepts was carried out in context of the banking sector. The study further explored the experience of TQM implementation in banks adopting this approach. The findings indicate that to ensure successful implementation of TQM in the banks, there are certain critical dimensions which needs to be addressed, viz: management commitment and support towards TQM, motivating and training of employees, and monitoring of customers' requirement through feedback. Beside this, it was also found that service quality is an important construct in banking sector and identifies four broad conceptual categories related to service quality. The finding will provide an understanding of the role of TQM and service quality in banking sector and it also provides useful direction for future research.
\end{abstract}

Keywords: Total quality management; Banking sector; Service quality; Service industry

\section{Introduction}

Liberalization and globalization of the banking sector has created an era of fierce competition, as a result of which service management and quality performance is expected to assume an increasing important role in these industries [1]. Banks can become stronger and effective only if they come out with better customer service, quality, costs, and innovation [2]. Today, customers have a wide choice of service providers and they would opt for only the best service providers in terms of quality, reliability, and profitability and who are at par with international standards. Therefore, the quality of service plays a dominant role and is a primary factor in ensuring the survival of the service provider in the global market. The whole focus is now concentrated on providing services to customer beyond his expectations. This concept is applicable to all service industries and has given birth to the concept of TQM in service sector $[1,3]$.

The popularity of TQM in manufacturing sector has encouraged a number of organizations to view its benefits and effect on organization performance. Several research papers have investigated the framework of successful TQM implementation [4-7].

The service quality of banks, especially perceived service, plays an important role in high-involvement industries like banks $[1,8]$. Leading academicians and researchers strongly believe that providing quality service to customers is not only the most important and effective factor for customer satisfaction but also the essential criterion that measures the competitiveness of a service organization like banks [1,8-11].

For survival, it is mandatory to provide best service quality and it is also viewed as pre-requisite to success of banking sector [12]. Many studies have proved that the performance of banks is significantly and positively linked with the service quality [13-15], and to achieve service quality in the banking sector, the TQM is highly essential $[8,16]$.

\section{Need of study}

Extent literature review suggests that voluminous research work has been done on the quality of services and relationship between service quality and organizational performance through TQM, but only a limited number of studies on TQM and service quality in the banking sector have been carried out. Researchers like Ahmed [17], Neyer [18], Sureshchandar et al. [19], Meyer and Dornach [20] have suggested the need of the present study to understand how banks can perform in a better way and what critical dimensions for success are so that they could be implemented to improve their financial performance, fulfill customer requirements and excel in quality of service.

\section{Aims and scope}

This study aims to present an overview of TQM in the banking sector together with the role of service quality in it so as to achieve organizational excellence. The study also identifies the key (critical) dimensions that help in the implementation of TQM in the banking sector. This study is a contribution to the academic work and attempts to provide a useful overview of TQM implementation and service quality in the banking sector.

Further, the paper is organized as follows. The next section presents TQM and service quality approaches followed by review of service quality in the banking sector. The subsequent section presents the review of TQM implementation together with the identification of critical dimensions for TQM in the banking sector. The final section discusses the conclusions of the present study along with the managerial implications and scope of future research.

\section{TQM and service quality}

The concept of service quality has emerged from TQM philosophy and now it is treated as an essential criterion for effective TQM

*Corresponding author: Faisal Talib, Assistant Professor, Mechanical Engineering Section, University Polytechnic, Aligarh Muslim University, Aligarh, India, Tel: +919412459748,E-mail: ftalib77@yahoo.co.in

Received November 25, 2011; Accepted April 19, 2012; Published April 22, 2012

Citation: Talib F, Rahman Z, Qureshi MN (2012) Impact of Total Quality Management and Service Quality in the Banking Sector. J Telecommun Syst Manage 1:102. doi:10.4172/2167-0919.1000102

Copyright: (c) 2012 Talib F, et al. This is an open-access article distributed under the terms of the Creative Commons Attribution License, which permits unrestricted use, distribution, and reproduction in any medium, provided the original author and source are credited. 
implementation. The literature review suggested that service quality can be categorized into number of ways such as customer service quality; online service quality; banking service product quality and automated service quality (explained in next section) [21,22] with the common aim to achieve customer satisfaction, improved financial performance, and competitiveness as shown in (Figure 1). Moreover, the figure also depicts that service quality is a multidimensional construct rather than having uni-dimensional meaning.

Also, literature review further shows that measuring service quality is not an easy task and lot of problems are there in measuring it. Most forms of measurement of service quality focuses on customer satisfaction. For instant, Cronin and Taylor [23,24], argue that measuring service quality using a performance-minus-expectations (SERVQUAL) basis is inappropriate and suggests that performanceonly (SERVPERF) measurement is a better method. However Parasuraman et al. [25], (PZB model) contend that the SERVQUAL scale using the expectations/performance gaps method is a much richer approach to measuring service quality and augment their earlier assertion $[26,27]$ that service quality is a multidimensional rather a unidimensional construct.

Brown et al. [28], highlights the challenges in conceptualizing and particularly measuring SERVQUAL using expectations and perceptions difference scores and proposed an alternative non-difference score approach as a more efficient way to measure service quality.

Nevertheless, banks reported that TQM leads to improvement of service quality $[8,29]$, bearing in mind the difficulty in adequately measuring the service quality and effect of TQM in service sector, they regularly conducted a customer satisfaction survey to evaluate their performance against past performance and benchmark themselves against their main competitors. In this way they continuously improve their service quality, involve and motivate their employees and empower them in decision making, thus leading to perfect implementation of TQM program in their organization.

\section{Service quality in banking}

Across all service industries, service quality remains a critical issue in maintaining and propagating business in the competitive marketplace [30]. To survive in a highly competitive service environment, it is apparent that service industries need to provide customer with high quality services. Customer today demand quality and from there point of view, quality is nothing but an integral and expected part of service, that is service quality [31].

In banking, quality means not just meeting but exceeding customer expectations. For this reason, service quality is viewed as an

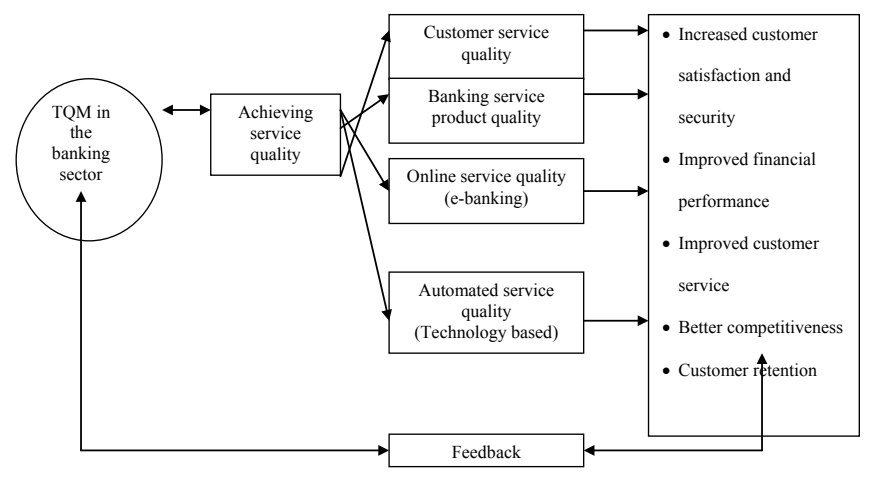

Figure 1: Service quality as a multidimensional construct in banking sector. important aspect in the banking industry. Further, it is evident that over the years, bank customers' perception of service quality has been changed tremendously. Today, quality includes a commitment towards continuous improvement and service relationships with customers. Also, the need for technology based services, new and improved product services, and e-services are also viewed as important aspects of banking service quality that supports improved and superior quality services provided to customer. Hence, these are the areas where banks have to focus upon in order to satisfy their customers.

Based on the literature review, the authors have identified the following four broad conceptual categories related to banking service quality:

- Customer service quality.

- Banking service product quality.

- Online/e-service quality.

- Automated service quality.

Customer service quality: Banking is a high involvement industry. Customers, whether at the retail or corporate level have always been important for banks. Customer satisfaction is highly related with service quality as service quality improves the probability of customer satisfaction [5], this results in commitment, intent to stay (customer retention), creation of a mutually rewarding relationship (bond) between the service provider and the user, increased customer tolerance for service failure and positive word-of-mouth advertising about the organization [32-34]. Banks now know that delivering quality service to customer is essential for success and survival in today's global and competitive banking environment [35].

In the era when intense competition is being greatly facilitated by technology, the need of providing adequate service quality will necessitate that banks have to focus attention on issues of improving, measuring and controlling their service quality and efficiency. Banking industries therefore should emphasize deeper penetration of the existing customer database. The data about customer needs and behavior enables organizations to identify today's key customer, develop relations with tomorrow's customers and estimate their future investment opportunities.

Banking service product quality: The bank product quality is primarily associated with product variety and diverse features. Banking service product quality plays a significant role in determining customer's perceptions of the overall banking service quality. Banks have increased emphasis on marketing a wide array of financial services in order to survive in the market due to tough competition [36]. Dixon [37], also argued that the key of getting more customers for the banks through the online service is not the attraction of the internet itself but the product offered to the customers. Bank customers wants variety of functions at one site and with ease like financial transactions, paying bills electronically and automatically, viewing their balance, monthly bank statements, purchasing shares and insurance, home loans with minimum rate of interest, purchasing cars and lands. Although banking service product quality is an intangible asset, it contributes to the competitive advantage in the banking industry. Therefore, it should be noted that continuously introducing and innovating the variety of banking service product quality to the current hi-tech customers can have unlimited access to financial information and enjoy a wider range of choices in selecting competitive products and financial institutions than ever before [38].

Online/internet/e-service quality: The concept of e-service 
emerged from the growth of the internet and information systems. The growth in internet-based services has changed the way that banks and customers interact [39]. E-service is conceptualized as an interactive information service that provides a means to organizations that can build its service offerings and develop a competitive advantage [40]. The basic reason behind development of online services was the cost reduction and to delight customers through automation [41]. Although firms gained efficiencies from online business/e-commerce/selling online, their failure to focus on customer needs and wants, resulted in poor online service performance [42]. The article by Liu and Arnett [43], considered the four quality factors as major ingredients for the success of website as: system use; system design quality; information quality and playfulness. Ribbink et al. [44], found five dimensions for e-service quality: assurance, ease of use, e-scape, responsiveness and customerization. Herrington and Weaven, examined four e-service quality dimensions: efficiency, fulfillment, availability and privacy. As for internet banking, Sathye [45] found two factors such as "difficulty in use" and "security concern" which are important reasons for consumers not opting for internet banking services.

Through this analysis it is concluded that the service quality features of internet/online banking which are critical for enhancing customer satisfaction such as the speed to download; content; design; interactivity; navigation; and security must be continuously improved.

Automated/technology service quality: Automated service quality is defined as the customer's overall evaluation of the excellence of services provided through electronic networks such as the internet, ATM, and telephone banking [22]. Customer evaluation of automated service option and their intention to use a particular option are directly affected by their perception of the attributes associated with that option [46]. The overall customer perception of automated service quality can be established through the quality of every automated delivery channel [10]. Many researchers have identified ATM, internet, and telephone banking as the principal automated delivery channels for retail banking [5]. Moreover, Dabholkar [47] argue that when the customer is in direct contact with the technology there is a greater control such as with internet banking, however, if there is no direct contact, such as with telephone banking, it is assumed that there is less control perceived by the customer during this transaction. Researchers also claims that reliability and user-friendliness with faster and more efficient service are important attribute in the evaluation of technology based services [15]. Overall, the need for technology to support superior service quality is viewed as very important factor for managing total quality in the banking sector.

\section{TQM implementation in banking sector}

This section reviews the implementation of TQM in banks. Use of TQM in the banking is not too old, earlier studies shows that TQM approach in the banking is a recent trend and is showing better performance after its implementation [4]. TQM, which is about total customer service and continuous customer satisfaction, is applicable to almost all service industries including banks where the customer is treated as king. In fact, customers in service industries, especially in the banking, are rather more sensitive to quality and delivery of service than their manufacturing counterpart as they are in direct contact with the service providers [48]. Therefore, adoption of TQM program in the banking sector may be one of the best alternatives that care about improved service quality and higher customer satisfaction together with retaining its customers.

A paper published in Total Quality Management Journal examines six case studies and concludes with key factors that led to successful
TQM implementation in the Turkish banking sector [29]. The results showed that successful TQM implementation requires: management's unwavering commitment to TQM and enthusiasm; formal national bodies to introduce organizations to TQM and provide assistance during and after TQM implementation; and a highly educated and competent management team.

A paper published in 2003 proposes a model linking perceived service quality, customer satisfaction, customer loyalty and employee satisfaction while implementing TQM amongst Australian and Korean banking industries [4]. The study further tested the developed model by using several measure and found significant relationships and path links between perceived service quality, customer satisfaction, and customer loyalty as well as between TQM practices and employee satisfaction.

A paper published in Managing Service Quality discusses the importance of training and education for TQM in banks of South Africa. Management commitment and managers understanding of TQM principles and methods was also found to be critical [49]. Results further showed that none of the organizations posses a well-developed TQM training strategy and plan.

A paper published in 2007 examines the critical success factors of TQM implementation in the UAE banking sector. 16 factors were found to be critical to TQM implementation success [8]. The factors are: top-management support; strategy; continuous improvement; benchmarking; customer focus; quality department; quality system; human resource management; recognition and reward; problem analysis; quality service technologies; service design; employees; servicescapes; service culture; and social responsibility.

Another study on assessing the need of TQM in the banking sector of the Northern Cyprus published in Journal of Transnational Management focused on implementing TQM principles in Turkish Cypriot banks [50]. He found that there is a need for updating and implementing new rational management methods followed by motivation and training of employees and employers. Further, he argued that continuous monitoring of customer satisfaction is also necessary to make TQM more effective.

A recent study published in 2009 presents the important total quality service factors in Indian commercial banks and examines the level of implementation of TQM practices in three groups of Indian banks [1]. The study reveals that the important TQM factors are:

- Top-management commitment.

- Human resource management.

- Technical and important systems

- Customer focus.

- Employee satisfaction.

- Service culture.

- Social responsibility.

- Servicesacpes.

Finally, a research study by Li et al. [50], surveys licensed bank in Hong Kong on the use of quality management practices. They tried to analyze the current status of quality management initiatives in Hong Kong and also compare the results with those from UK financial institutions in 1994. The result shows that they have 68 percent success rate for quality initiatives. They have also gained customer satisfaction, 
efficiency, and quality awareness. They tend to devote more effort in meeting service standards and providing prompt services.

Similar studies on TQM and service quality in the banking sector by Joseph and Stone $[2,5,15,51]$ are of interest too.

\section{Conclusions}

As the banking industries become more involved in implementing TQM and service quality concepts, questions like which key practices should be accentuated and how should the TQM be implemented in the banks to achieve desired outcome of customer satisfaction, improved financial performance, and providing better competitiveness, needs to be answered. This paper seeks to provide answers to these questions.

From the review of literature it was found that several dimensions are responsible which are critical for success of TQM in the banking sector. In order to ensure a successful implementation of TQM in the banks, there is a need to motivate employees to improve the level of services provided by them. Also, appointment of qualified and competent managers will successfully contribute to the management of the banks together with giving enough training and education to employees so that they understand specific quality policy and TQM strategy. Lastly, monitoring the customer satisfaction and taking the feedback frequently would further improve the performance of the banking sector. Above all there is a need of top-management commitment towards TQM and giving full support for its successful implementation.

Many authors have identified different service quality dimensions which are associated with the banking sector. Present study categorizes these dimensions into four groups which are directly responsible for effective TQM implementation in the banking sector.

It is concluded that if these service quality attributes are taken care of, that will result in excellence in the banking performance.

To summarize, TQM is essential to the banking sector in particular and other service-oriented organizations in general to sustain competitive advantage. The result of TQM often takes time and is a long-term process. But TQM is a step in the right direction.

\section{Managerial implications}

The banking sector has maintained good progress with the advent of new service technologies; value added services, and creation of new banks. At this juncture, the present study could help the managers of the service organizations:

- To focus on understanding the needs of the customers and strive to provide the product and services that fully meets the same in order to survive in this highly competitive industry.

- To pay attention on different banking service quality and continuously improve them for customer satisfaction and retention.

- To update themselves in using different quality improvement tools and techniques in the banking sector to gain competitive advantage.

The findings of the present study suggest some directions for further research. More extension of this paper could take the form of replicating the study in other service industries such as healthcare; education; IT/IS etc. and also can use the findings of the present research as a hypothesis for a survey research using data to develop a valid instrument to identify the critical success factors for TQM implementation in developing countries.

\section{References}

1. Selvaraj M (2009) TQM in Indian commercial banks: a comparative study. Journal of Marketing and Communication 4: 59-70.

2. Cowling A, Newman K (1995) Banking on people: TQM, service quality, and human resources. Personnel Review 24: 25-40.

3. Saravanan R, Rao KSP (2006) An analysis of total quality service dimensions in service sector-a case study. International Journal of Management and Systems 22: 261-267.

4. Kayis B, Kim H, Shin TH (2003) A comparative analysis of cultural, conceptual and practical constraints on quality management implementations--findings from Australian and Korean banking industries. Total Quality Management \& Business Excellence 14: 765-777.

5. Joseph M, Stone G (2003) An empirical evaluation of US bank custome perceptions of the impact of technology on service delivery in banking sector. International Journal of Retail and Distribution Management 31: 190-202.

6. Talib F, Rahman Z (2010) Studying the impact of total quality management in service industries. International Journal of Productivity and Quality Management 6: 249-268.

7. Silvestro R (2000) Towards a contingency theory of TQM in services - How implementation varies on the basis of volume and variety. International Journal of Quality and Reliability Management 18: 254-288.

8. Al-Marri K, Ahmed AMMB, Zairi M (2007) Excellence in service: an empirical study of the UAE banking sector. International Journal of Quality and Reliability Management 24: 164-176.

9. Berry LL, Parasuraman A, Zeithaml VA (1994) Improving service quality in America: lessons learned. Academy of Management Executive 8: 32-52.

10. Al-Hawari M, Hartley N, Ward T (2005) Measuring banks' automated service quality: a confirmatory factor analysis approach. Marketing Bulletin 16: 1-19.

11. Arasli H, Mehtap-Smadi S, Katircioglu ST (2005) Customer service quality in the Greek Cypriot banking Industry. Managing Service Quality 15: 41-56.

12. Roger H, Schlesinger LA, Zornitsky J (1996) Internal service quality, customer and job satisfaction: linkages and implications of management. Human Resource Planning 20: 31.

13. Krishnaveni $R$, Divya $P$ (2006) Insight into the internal service quality in America: lesson learned. Academy of Management Executive 8: 32-44.

14. Vanniarajan T (2007) Internal service quality and performance outcomes in Commercial banks. Global Management Review 1: 22-31.

15. Joseph M, McClure C, Joseph B (1999) Service quality in the banking sector: the impact of technology on service delivery. International Journal of Bank Marketing 17: 182-193

16. Kassem SM (1998) Service marketing: The Arabian Gulf Experience. Journa of Services Marketing 3: 61-71.

17. Ahmed AM (2002) Virtual integrated performance measurement. International Journal of Quality and Reliability Management 19: 414-441.

18. Neyer PU (2000) An investigation into whether complaining can cause increased customer satisfaction. Journal of Customer Marketing 17: 9-19.

19. Sureshchandar GS, Chandrasekharan R, Anantharaman RN, Kamalanabhan TJ (2002) Management's perception of total quality service in the banking sector of developing economy- a critical analysis. International Journal of Bank Marketing 20: 181-196.

20. Meyer A, Dornach F (1997) The German Customer Barometer 1995. Quality and Satisfaction, Year book of Customer Satisfaction in Germany, German Marketing Association/German Post AG, Düsseldorf/Bonn.

21. Jun M, Cai S (2001) The key determinants of internet banking service quality: a content analysis. International Journal of Bank Marketing 19: 276-291.

22. Al-Hawari M, Ward T, Newby L (2009) The relationship between service quality and retention within the automated and traditional contexts of retail banking Journal of Service Management 20: 455-472.

23. Cronin JJ, Taylor SA (1992) Measuring service quality: a re-examination and extension. Journal of Marketing 56: 55-68. 
Citation: Talib F, Rahman Z, Qureshi MN (2012) Impact of Total Quality Management and Service Quality in the Banking Sector. J Telecommun Syst Manage 1:102. doi:10.4172/2167-0919.1000102

Page 5 of 5

24. Cronin JJ, Taylor SA (1994) SERVPERF versus SERVQUAL: reconciling performance-based and perceptions-minus-expectations measurement of service quality. Journal of Marketing 58: 125-131.

25. Parasuraman A, Zeithaml VA, Berry LL (1994) Reassessment of expectations as a comparison standard in measuring service quality: implications for further research. Journal of Marketing 58: 111-124.

26. Parasuraman A, Zeithaml VA, Berry LL (1985) A conceptual model of service quality and its implications for future research. Journal of Marketing 49: 41-50.

27. Parasuraman A, Berry LL, Zeithaml VA (1993) More on improving service quality measurement. Journal of Retailing 69: 140- 147.

28. Brown TJ, Churchill GA, Peter JP (1993) Improving the measurement of service quality. Journal of Retailing 69: 127-139.

29. Mellahi K, Eyuboglu F (2001) Critical factors for successful total quality management implementation in Turkey: evidence from the banking sector. Total Quality Management 12: 745-756.

30. Kandampully J, Duddy R (1999) Competitive advantage through anticipation, innovation and relationships. Management Decisions 37: 51-56.

31. Kandampully J (1997) Firms should give loyalty before they can expect it from customers. Managing Service Quality 7: 92-94.

32. Newman K (2001) Interrogating SERVQUAL: a critical assessment of service quality measurement in a high street retail bank. International Journal of Bank Marketing 19: 126-139.

33. Gounaris SP, Stathakopoulos V, Athanassopoulos AD (2003) Antecedents to perceived service quality: an exploratory study in the banking industry. International Journal of Bank Marketing 21: 168-190

34. Heskett JL, Sasser WE, Schlesinger LA (1997) The Service Profit Chain. Free Press, New York, NY

35. Wang Y, Lo HP, Hui YV (2003) The antecedents of service quality and product quality and their influences on bank reputation: evidence from banking industry in China. Managing Service Quality 13: 72-83.

36. Strieter J, Gupta AK, Raj SP, Wilemon D (1999) Product management and the marketing of financial services. International Journal of Bank Marketing 17 342-355.

37. Dixon M (1999) Com madness: 9 must-know tips for putting your bank online America's Community Banker 8: 12-15.
38. Mols NP (2000) The internet and services marketing-the case of Danish retail banking. Internet Research 10: 7-18.

39. Yang Z, Peterson RT, Huang L (2001) Taking the pulse of Internet pharmacies Mark Health Serv 21: 4-10.

40. Bauer HH, Hammerschmidt M, Falk T (2005) Measuring the quality of e-banking portals. International Journal of Bank Marketing 23: 153-175.

41. Rust R, Kannan P (2003) E-service: a new paradigm for business in the electronic environment. Communications of the ACM 46: 36-42.

42. Loonam M, O'Loughlin D (2008) Exploring e-service quality: a study of Irish online banking. Marketing Intelligence and Planning 26: 759-780.

43. Liu C, Arnett KP (2000) Exploring the factors associated with Website success in the context of electronic commerce. Information and Management 38: 23-33.

44. Ribbink D, Van Riel A, Liljander V, Streukens S (2004) Comfort your online customer: quality, trust, and loyalty on the internet. Managing Service Quality 14: $446-456$

45. Sathye M (1999) Adoption of internet banking by Australian consumers: an empirical investigation. International Journal of Bank Marketing 17: 324-334.

46. Dabholkar P (1996) Consumer evaluations of new technology-based selfservice options: an investigations of alternative models of service quality. International Journal of Research in Marketing 13: 29-51.

47. Dabholkar PA (1994) Technology based service delivery. Advances in Services Marketing and Management 3: 241-271.

48. Safakli O (2004) Assessing the need of TQM in the Banking Sector of the Northern Cyprus. Journal of Transnational Management 10: 59-72.

49. Vermeulen W, Crous MJ (2000) Training and education for TQM in the commercial banking industry of South Africa. Managing Service Quality 10 61-67.

50. Li EY, Zhao X, Lee TS (2001) Quality management initiatives in the banking industry: a Meta analysis of Hong Kong and the UK. International Journal of Quality and Reliability Management 18: 570-584.

51. McCabe D, Hutchinson I (1994) Quality Initiatives in the Financial Services Manchester, UK, Manchester School of Management, UMIST. 